\title{
ФОРМУВАННЯ ЕМОЦЙНОГО ІНТЕЛЕКТУ \\ В МЕНЕДЖЕРІВ-МАГІСТРІВ В ІНСТИТУТІ ПІСЛЯДИПЛОМНОЇ ОСВІТИ ТА МЕНЕДЖМЕНТУ
}

\author{
Черновол-Ткаченко P. I. \\ кандидат педагогічних наук, професор, директор Інституту підвищення \\ кваліфікації педагогічних працівників і менеджменту освіти, \\ Харківський національний педагогічний університет \\ імені Г. С. Сковороди,м. Харків, Україна
}

У статті висвітлено форми і методи роботи науково-педагогічних працівників вишу по формуванню емоційного інтелекту у майбутніх менеджерів. Розкрито сутність емочійного інтелекту та його роль у управлінській діяльності керівника організації. Виписано поради щцодо розвитку иього феномену у практичній роботі менеджера.

Ключові слова: інтелект, емоційний інтелект, управлінські компетентності і компетениії.

The article reflects the forms and methods of work of scientific and pedagogical workers of the university on the formation of emotional intelligence in future managers. The essence of emotional intelligence and their role in the management activities of the head of the organization are revealed. Written out tips for the development of this phenomenon in the practical work of the manager.

Key words: intelligence, emotional intelligence, managerial competencies.

Утвердження демократії в суспільстві обумовлює відтворення його інтелектуальних і продуктивних сил, спрямованих на формування мобільної, духовно-культурної, конкурентоспроможної особистості, здатної інтегруватись у міжнародний освітній простір. На жаль, сучасна освіта здебільшого формує у ії здобувачів засвоєння готових знань і не продукує умови їх оновлення і нарощування. Отже, вона не готує фахівців, здатних працювати творчо, самостійно, особливо коли знання потребують постійного неперервного вдосконалення шляхом активної пізнавальної діяльності.

Вкладене вище спонукає до конструктивних змін у процесі підготовки фахівців зі спеціальності 073 «Менеджмент» для освітньої і господарської галузей. Здійснимо невеличкий екскурс у становлення даної спеціальності. Її утвердження датовано з 2000 року у закла- 
дах вищої освіти за спеціальністю специфічні категорії 8.000009 «управління навчальним закладом» та класифікатором професій 12 «керівник підприємства, установи та організації (у сфері освіти та виробничого навчання)». 3 цього часу це вже стала професія, а не посада (як раніше) на яку призначали з числа кращих вчителів, хоча така практика не завжди приносила позитивні результати. Так було розпочато підготовку керівників освітньої галузі. 32006 року галузь знань специфічні категорії була змінена на спеціальність 8.18010020 «Управління навчальним закладом». Згідно наказу МОН України № 1565 від 19.12.2016 року галузь знань специфічні категорії перейменовано в 07 «Управління та адміністрування» за спеціальністю 073 «Менеджмент».

У наукових розвідках стверджують, що менеджери, які володіють високим рівнем емоційного інтелекту, якісно й ефективно забезпечують досягнення цілей організації. Перш ніж зосередитись на цьому феномені, розглянемо поняття «інтелект». Ми дотримуємось позицій, що інтелект найбільш поєднується з поняттями розум, мислення, пізнання, розвиток. Не можна не погодитись 3 дослідниками, що розум розуміє зрозуміле, а інтелект намагається зрозуміти незрозуміле [2]. Таким чином, основною функцією інтелектуала є здатність до мисленнєвої діяльності у наростаючому процесі, щоб творити, виробляти щось нове, неповторне, оригінальне, незвичне.

Метою нашої розвідки не є поглиблене вивчення інтелектуалів, їхньої виняткової розумової діяльності та складних мотивів. Наша увага буде зосереджена на соціальній функції інтелектуала у єдності 3 його емоційною складовою, тобто емоційним інтелектом менеджерафахівця з управління. Саме тлумачення «емоційний інтелект» не має усталеного визначення як серед науковців, практиків, так і в словниках та енциклопедіях. Саме оволодіння ним обумовлює менеджерові, як уже зазначалося, грамотне оцінювання виробничої ситуації, забезпечує стримування власних емоцій, розвиває уміння не піддаватись на провокації, що можуть спричинити не лише моральні, а й матеріальні збитки.

Практичний досвід переконує, що успішними є ті менеджери, які виважені, толерантні, емоційно стримані, стресостійкі. Саме вони здатні вивести системно і послідовно організацію з кризи, мудро усунути конфлікт. Отже, щоб стати успішним управлінцем будь-якого 
рівня, необхідно навчитися володіти не лише власними емоціями, а й вміло взаємодіяти з емоціями оточуючих.

У процесі опанування таких навчальних дисциплін як «Менеджмент», «Стратегічний менеджмент», «Психологія управління», «Професіограма керівника» науково-педагогічні працівники нашого інституту використовують різноманітні методики і технології, щоб розвивати емоційний інтелект у майбутніх менеджерів.

Ми поділяємо наукові позиції, що у загальному розумінні емоційний інтелект - це здатність працювати з емоціями і проявляти емпатію [1].

В основі діяльності менеджера будь-якого рівня має бути вміння управляти людьми для досягнення високих результатів у будь-якій сфері діяльності. Наукові розвідки переконують, що вирішення цієї проблеми криється саме в ідеї емоційного інтелекту, як здатності особистості глибоко проникати в ситуацію і точно іiї відчувати; не тільки розуміти бажання членів колективу, а й вміти прогнозувати його за відповідних змін у культурі організації. I, головне, - це витримка під час впливу негативних емоцій. Виваженість і спокій - запорука раціонального рішення [3].

Послуговуючись на вище викладене, під час занять «Психологія управління» викладач формує у майбутніх менеджерів такі компетентності: майстерність прозоро і переконливо спілкуватися зі співбесідником; здатність проявляти емпатію у будь-якому комунікативному середовищі, що забезпечує комфортність у стосунках; уміння використовувати власні недоліки і переваги на користь у вибудові свого життєвого плану; навички зберігати стабільні здорові стосунки за рахунок упередження деструктивного впливу своєї емоції.

Під час виконання самостійної роботи пропонуємо здобувачам освіти проаналізувати різні види конфліктів 3 матеріалів періодичної преси чи Інтернету. А саме: міжособистісні, між собою і групою, міжгрупові, між керуючою і керованою системами. Розкривши зміст конфлікту, необхідно виконати наступні завдання:

1. Змоделювати процес управління конфліктом.

2. Визначити в якій фазі знаходиться конфлікт.

3. Назвати недоліки та переваги міжособистісних і структурованих методів подолання конфлікту. 
4. Спрогнозувати результат залежно від використаного методу.

5. Обгрунтувати на якому етапі менеджер може запобігти конфлікту.

Такий вид роботи забезпечує формування і розвиток емоційного інтелекту здобувачів освіти. Вони удосконалюють компетентності і компетенції в управлінні в умовах невизначеності, ризику.

Моніторинг обробки результатів виконаної роботи засвідчив наступне. Для процесу управління конфліктом майбутні менеджери надали перевагу таким діям: цілеспрямованість на динаміку конфлікту задля досягнення консенсусу; застосування оптимальних стилів поведінки, що сприяють адекватному розв’ язанню конфліктних ситуацій; використання системи винагород для примирення сторін.

3'ясувати фазу, в якій знаходиться конфлікт було запропоновано такими заходами: аналіз мотивів, цілей, здатностей, особливостей характеру професійної компетентності всіх учасників конфліктної ситуації; вибір ситуації, яка найбільш відповідає стилю поведінки конфліктуючих; з'ясування рівня усвідомлення конфліктної ситуації хоча б у одного із учасників.

Стосовно прогнозування методів подолання конфлікту було надано преференції таким: окремо вислухати позицію кожного конфліктуючого, толерантно наголошуючи: «А якби ви були на його місці?»; чи не доцільніше дійти згоди чи примирення, пам'ятаючи правило бумерангу; одна сторона може перебільшувати свої вимоги, щоб потім виявитися великодушною і таким чином першою піти на вдавані поступки.

Працюючи над цим завданням здобувачі освіти обгрунтували роль менеджера на стадії запобігання конфлікту як людину, яка має передбачати загострення і упереджувати його приховуванням від членів колективу, проводити індивідуальні розслідування; іноді дієвим є правило «кнута і пряника»; оперативно вирішувати конфлікт не чекаючи його загострення.

Удосконалюючи і розвиваючи емоційний інтелект здобувачів освіти, пропонуємо їм обрати одну з позицій наростання конфлікту, де необхідно визначити, що спричинило його наростання і як це вирішити:

1. Взаємне негативне ставлення сторін одна до одної.

2. Наявність суб'єктів, що мають протилежно спрямовані мотиви або судження. 
3. Наявність стану протиборства між учасниками суперечності.

4. Моральні та матеріальні наслідки у процесі зіткнення.

Прихильники першої позиції (негативне ставлення сторін) вважають, що рівень конфлікту можна упередити матеріальним зацікавленням сторін, доручивши їм спільну справу за винагороду за умов тісної співпраці і порозуміння.

За умов другої ситуації (протилежні погляди) запропоновано вислухати точку зору кожного окремо і спрямувати учасників на розробляння індивідуального проекту з обрахуванням матеріальних переваг. Результати оцінюють незалежні експерти.

У стані протиборства менеджери-магістри вважають доцільним застосування адміністративного методу. Керівник має оголосити власну позицію стосовно суперечки і наголосити, що на даний час обидві сторони далекі від вирішення проблеми. Право вибору він залишає за собою.

Стосовно моральних і матеріальних наслідків у процесі зіткнення здобувачі освіти заявили, що рівень IQ керівника не відповідає сучасним вимогам до управління організацією.

Безумовно, що викладені навчальні заходи, не вичерпують усі варіанти вирішення проблем, але засвідчує певні позитивні сторони в управлінській діяльності майбутніх менеджерів у становленні їх як майстрів-професіоналів.

\section{Список використаних джерел:}

1. Передало Х. С. Роль емоційного інтелекту у системі основних компетенцій менеджера. Менеджмент та підприємництво в Україні: етапи становлення та проблеми розвитку. Vol. 2. № 2. 2020. С. 63-69.

2. Що таке інтелект? Хто такі інтелектуали та чого вони прагнуть? URL: http://iee.org.ua > publication (дата звернення: 02.10.2021).

3. Що таке емоційний інтелект, для чого він потрібен і як його розвинути в собі. URL: https://blog.agrokebety.com/shcho-take-emotsiynyy-intelekt (дата звернення: 05.10.2021). 